https://doi.org/10.31516/2410-5333.060.11

UDC 004.738.5:006.07:35

\title{
N. Khymytsia
}

Candidate of Historical Sciences, Assistant Professor, Lviv Polytechnic

National University, Lviv, Ukraine

nataliia.o.khymytsia@|pnu.ua

https://orcid.org/0000-0003-4076-3830

\section{HISTORIOGRAPHICAL CHARACTERISTICS OF THE AGGREGATED DATA PUBLISHED ON THE OFFICIAL FACEBOOK PAGES OF THE LVIV REGIONAL STATE ADMINISTRATION}

The article is devoted to the analysis of a separate class of historical sources aggregated data and the format of their presentation in the Ukrainian segment of the Internet, in particular, on the official Facebook pages of the authorities and administration of Ukraine. The groups, types, and kinds of aggregated data that can be used in the research activities of the historian, if for some reason such information is not available on other resources, were described. The question of qualitative characteristics of different types of aggregated data is considered, namely: significance, validity, relevance. An assessment is given of the studied array of summary data of such types as departmental statistics, expert data, the content of publications, information about events available on the official Facebook pages of the Lviv Regional State Administration (LRSA), and analysis of their historiographical characteristics.

Keywords: social communications, research, mass sources, content, aggregated data, statistics, surveys, methods, sampling, data analysis, public authorities, web communities, social networks.

\section{Н. Химиця}

кандидат історичних наук, доцент, Національний університет «Львівська політехніка», м. Львів, Україна

\section{ІСТОРІОГРАФІЧНІ ХАРАКТЕРИСТИКИ ЗВЕДЕНИХ ДАНИХ, ОПУБЛІКОВАНИХ НА ОФІЦІЙНИХ ҒАСЕВООК-СТОРІНКАХ ЛЬВІВСЬКОЇ ОБЛАСНОЇ ДЕРЖАВНОЇ АДМІНІСТРАЦІЇ}

Актуальність. Сучасні темпи розвитку Інтернету сприяють його швидкому перетворенню на нове середовище та засіб історіографічного дослідження. Для науковця-історика важливі різні види історіо-графічної інформації в мережі Інтернет. Серед об'єктів історіографічного аналізу особливе значення мають зведені дані органів влади. У поєднанні з традиційними методами джерелознавчого дослідження здійснення аналізу, моніторингу та вибірки зведених даних надає не лише додаткових можливостей для вивчення суспільно-політичних подій, а також дозволяє використовувати ці дані для прогнозування та моделювання.

Мета статті - проаналізувати зведені дані, опубліковані на офіційній сторінці Facebook спільноти виконавчого органу влади України та визначити їх історіографічні характеристики.

1 This work is licensed under a Creative Commons Attribution-NonCommercial-ShareAlike 4.0 International License. 
Методологія. Для виконання дослідження використано аналітичний метод, методи опису, зіставлення та узагальнення.

Результати. Описано групи, категорії та види зведених даних. Виокремлено види зведених даних, що можуть використовуватися в дослідницькій діяльності історика та роботі інформаційних агентств й інформаційноаналітичних служб. Конкретизовано методологічні проблеми, які можуть виникати під час використання зведених даних у дослідницькій практиці. Розглянуто питання якісних характеристик різних видів зведених даних, а саме: об'єктивність, актуальність, змістовність, своєчасність, точність, повнота. Подано оцінку зведених даних таких видів як відомча статистика, експертні дані, зміст публікацій, інформація про події, що доступні на офіційних facebook-сторінках Львівської обласної державної адміністрації (ЛОДА) та визначено їх історіографічні характеристики.

Новизна. У цьому дослідженні вперше здійснено аналіз історіографічних характеристик зведених даних, опублікованих на офіційних facebookсторінках ЛОДА.

Практичне значення. Матеріали та висновки дослідження можна використовувати з метою інформаційного забезпечення історичних досліджень. Вони стануть корисними також для державних органів управління, інформаційних агентств та інформаційно-аналітичних служб.

Висновки. Аналіз масивів зведених даних, доступних на офіційних сторінкаx facebook-спільнот, $є$ інноваційним і важливим елементом дослідження суспільно-історичних процесів в Україні. На базі такого аналізу також формуються основні вимоги вивчення конкретних проблем, пошук найприйнятніших їх вирішень і визначення необхідних для цього технологічних засобів та прийомів діяльності. Дослідження суспільно-історичних процесів методом аналізу зведених даних покликані вирішувати завдання прогнозування та моделювання подальшого розвитку міста, регіону, країни.

Ключові слова: соціальні комунікації, дослідницька діяльність, масові джерела, контент, зведені дані, статистика, опитування, аналіз даних, органи державної влади, вебспільноти, соціальні мережі.

Introduction. Today, historical science has a unique opportunity to quickly access a wide range of mass sources. The information contained in them, with the help of quantitative research methods, allows studying out similar, common features and trends (regularities and trends) that are inherent in real social phenomena. With the use of such techniques, the shortcomings of the "illustrative" approach in historical research. The use of such sources for basic historical research, which studies the impact of crisis moments, important events, revolutionary periods and on this basis develop strategies to prevent the negative consequences of socio-political upheavals in the future, is especially important.

A significant amount of such consolidated data the Ukrainian historian can get from the official Facebook resources of the communities of government and administration.

The validity, relevance, and quality of such aggregated data, on the one hand, are determined by the adopted standards and requirements for 
the documentation and information component of such organizations, and on the other hand by Facebook's technical capabilities to generate and structure information received as a result of feedback.

Related works. To this type of sources, the scientist includes: "sources that characterize such objects of reality that form certain social systems with appropriate structures" (Kovalchenko, 2003). The most common types of mass sources, according to I. D. Kovalchenko are: statistical materials (census and survey), materials of office work and personal accounting, systematized reference materials, the sources that allowed to study mass processes and phenomena, and in which the information was contained in an aggregated (generalized) form. American professor Tomas C. Owen in his works focuses on the use of Database of Corporations for historical research (Owen, 1992). Scientific conclusions in the works of G. Perelman are based on statistical data. In his paper, he compares the dynamics of industrial indexes of stocks traded on London and St. Petersburg exchanges at the end of XIX - the early $\mathrm{XX}$ century and shares practical advice on the technology of transferring a significant volume of printed sources into electronic database format (Perelman, 2009; Perelman, 2005). In his works, the Russian historian L. Borodkin uses as the main sources: Russian industrial and financial statistics, databases and big data. Also, numerous works of the scientist thoroughly describe the use of mathematical modeling of long-term sociohistorical processes, theoretical history, historical macrosociology, creation, and analysis of historical databases, research of social evolution, historical demography (Borodkin, 2019; Borodkin, 2005; Borodkin, 2016; Borodkin, Ertz, 2003; Borodkin, Leonard, 2000; Borodkin, Granville, Leonard, 2007). Peter Dorn visually examines the structure of digital research archive collection in terms of metadata for saved datasets (Scharnhorst, Bosch, Doorn, 2012). M. A. Pol'ovyy practices mathematical methods in the study of integrated indicators of socio-economic development (Polyvovyy, 2014). S. Golub and N. Khymytsia, by using aggregated data and monitoring information systems, offer new approaches in conducting cliometric research (Holub, Khymytsia, 2016; Holub, Khymytsia, 2018; Khymytsia, Lisina, Morushko, Zhezhnych, 2017; Khymytsia, Ustyianovych, Dronyuk, 2019).

However, most of the analyzed studies do not take into account the potential of mass sources and aggregated data available through the official pages of organizations on social networks, which in our opinion significantly affects the quality of historical publications and limits the development of domestic historiography.

The purpose of our study is to analyze the aggregated data published on the official Facebook pages of the authorities and administration of Ukraine and determine their historiographical characteristics. 
The types and kinds of aggregated data. According to research, social networks rank first among electronic tools used in their activities by public authorities and management, state enterprises, public organizations. At the same time, in those organizations that use social networks, Facebook is the most popular (99\% of organizations use this network). The use of social networks gives organizations several advantages:

- improves the transparency, management, and accountability of organizations - provide information about the funds spent (written acts, photo reports);

- helps organizations to interact directly with audiences through a simple and cost-effective environment (PR, informing about the organization, its mission, achievements, dissemination of important information);

- helps to quickly disseminate timely information (current announcements, fundraising);

- creates a transparent place for public discussion (solving local problems (building, cleaning), promoting the idea;

- helps to create a highly sensitive civil society (crowdfunding and crowdsourcing; networking and coalition building);

- helps organizations to attract segments of the population that are difficult to reach with the help of traditional media (organization of mass actions: protests, rallies).

As a result of such activities of public authorities and management, a large array of statistics and consolidated data is created and accumulated in the network, such information that characterizes a group or community of individuals as a whole.

Researchers J. Mannheim and R. Rich in their work (Mannheim, Rich, 1997) identify two main groups of consolidated data:

The first group is aggregated data that reflects the characteristics of many group characteristics, formed by combining data on the behavior of all members of the group. The aggregated data, for example, include the population of the state. Birth rate, mortality, literacy, crime - are all aggregated indicators obtained by adding all the relevant individual events (deaths, births, crimes, etc.) in a group and expressed in standardized units (for example, per thousand population)). Such aggregated data reflect the amount of a group trait (or property) that group members do not have separately (Mannheim, Rich, 1997, p. 292). Essential indicators of consolidated data of this type are the so-called coefficient of belonging to a particular social or political process/phenomenon. In addition, such data are a measurement of aggregate characteristics.

The second group - aggregated data that reflect the number of group characteristics, which is derived not from the combination of characteristics 
of individual members of the group, but from the system properties of the group. That is, these are system indicators. The form of government, for example, is a systemic variable, and a democratic or undemocratic form of government can be established in any state, regardless of how individual citizens behave and hold democratic and non-democratic views. Similarly, the state budget can be spent on government needs, regardless of the importance attached to the respective needs and problems of individual residents of this country.

Data from both of these classes, which relate to different types of groups, can be obtained from different sources. Groups can be divided into two categories: territorial groups (which are determined by the residence of their members within a certain geographical area, for example, state, city or individual district) and demographic groups (which are determined by the personal characteristics of their members, such as nationality or occupation).

The use of aggregate data is associated with certain methodological aspects. However, the benefits that the researcher receives from the use of aggregate data significantly outweighs the possible difficulties in the process of finding them. The use of aggregated data may be necessary and necessary when individual data (those that constitute a personal secret) are not available or are very expensive/expensive to obtain.

Main types of consolidated data, according to the classification of J. Mannheim and R. Rich: the census data, the departmental statistics, the sample polls, the content of publications, the event information, the expert data.

Monitoring of the aggregated data published on the official Facebook pages of the authorities and administration of Ukraine. To conduct the study, the official Facebook pages of regional councils were selected. Consider the types of aggregated data that are presented on these resources.

The following aggregated data are valuable for the historian's research work on the official Facebook page of the Lviv Regional State Administration (LRSA):

- content of publications,

- departmental statistics,

- information about events,

- expert data.

The most complete, informative, and relevant are the aggregated data belonging to the type "content of publications". Valuable for historical research are the publications-appeals of the Chairman of the LRSA, which are published with a certain frequency, relate to current events in the region or in the country, and contain some statistics and expert assessments. Based on the content analysis of such publications, the researcher has the opportunity to draw the most reasoned conclusions. 


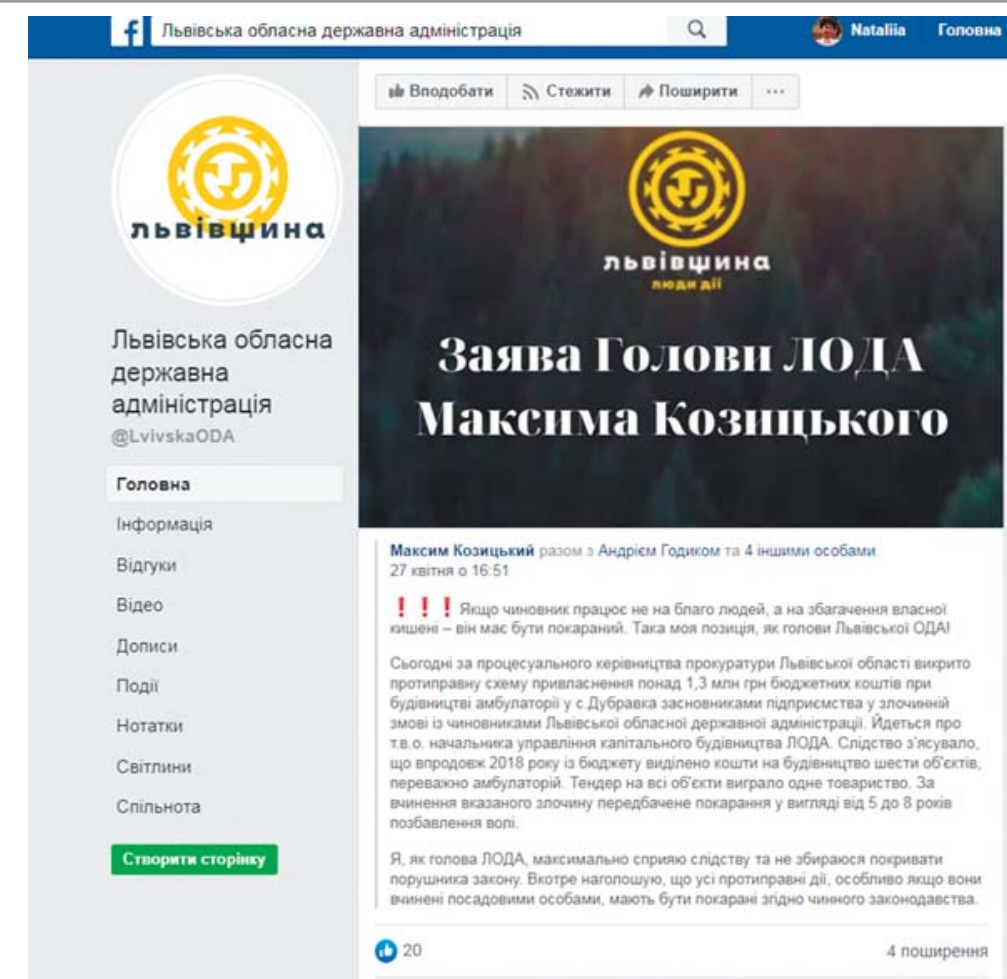

Fig. 1. An example of aggregated data - the content of the publication.

Content containing departmental statistics is also available on the official LRSA Facebook page. Such aggregated data highlight quantitative indicators on the status of implementation of important areas of public policy in the region, also contain relevant information on projects and activities initiated by the LRSA, on planning/implementation of the investment program and investment funds provided in the budget for the coming years. A methodological feature of the collection and processing of such information is the possibility of in-depth search of statistical data on the official pages of the LRSA departments.

An array of aggregated data is presented on the pages of the LRSA departments. Mainly, it is information about important events related to the direction of the unit and statistics on the implementation of projects and programs.

Also on the resources of the departments are available publications on the decisions of the session of the LRSA and the LCC, relating to the profile activities of these units. 


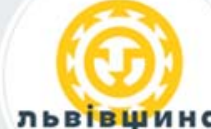

Львівська обласна державна адміністрація

@LvivskaODA

Головна

Інформація

Відгуки

Bigeo

Дописи

Подіi

Нотатки

Світлини

Спільнота

Crвopwru cropinay

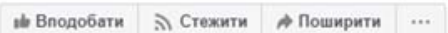

13 подобаеться Ф Коментувати $\Rightarrow$ поширити

6. Напишіть коментар

(ㄱ) (앙 $(2)$

\section{Львівська обласна державна адміністрація}

21 ввітня $0.09 .05 \cdot \odot$

ОНОВЛЕНА ІНФОРМАЦІЯ СТАНОМ НА 09.00 ГОДИНУ ! ! !

У період з 23:00 год 20 квітня по 8:30 год 21 квітня, в області з підозрою на коронавірусну інфекцію звернулися ще 5 осіб.

Пацієнти з міста Львова та Моршина.

Про це повідомляє лікар-епідеміолог Львівської обласної інфекційної клінічної лікарні, головний позаштатний спеціаліст департаменту охорони здоров'я облдержадміністрації з епідеміологї Наталія Тімко.

Зараз на лікуванні у Львівській

обласній інфекційній клінічній лікарні -

100 ociб.

На самоізоляції знаходяться 935 осіб. За увесь час виписано - 203 паціента. Стан більшості хворих -середньої вахкості. У 14-ти паціентів стан важкий. Немає пацієнтів на апараті ШВЛ. Двоє пацієнтів у відділенні інтенсивної терапіі.

Загалом на Львівщині за весь час із підозрою COVID- 19 звернулася 1241 пюдина.

За увесь час в сумі у 900 пацієнтів Львівської області не підтвердили діагноз коронавірус.

Станом на зараз, на Львівщині з підоою на коронавірус $є 96$ осіб. У 256 паціентів позитивний результат тесту на коронавірус, з них 10 осіб померли. 26 пацієнтів одужали.

(3) Подобаеться $\square$ коментувати $\quad \Rightarrow$ поширити

Fig. 2. An example of aggregated data - departmental statistics.

However, on the example of the official Facebook pages of the LRSA departments, we can note that the number of published posts is much smaller, the frequency of their appearance is also very different. This significantly affects the quantity and quality of content that contains the aggregated data needed for historical research.

The aggregated data "information about events" on the official Facebook page of the LRSA is presented in the form of announcements: announcements of briefings, plenary sessions, meetings, reporting days by various departments. The content of this type contains important information about the work plan of the meeting, the results and decisions of the meeting, and plans to improve the situation. It is also important to use the archive of events initiated and conducted by this public authority to confirm certain conclusions of the researcher. 


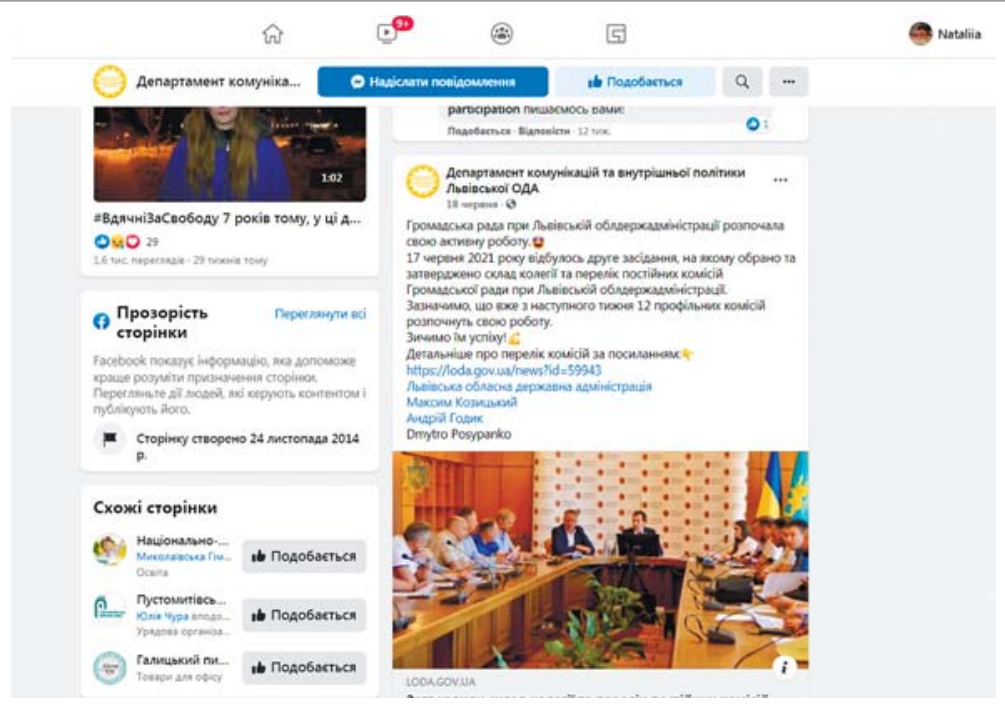

Fig. 3. An example aggregated data - information about events.

The type of "expert data" is available on the official Facebook page of the LRSA and on Facebook pages of the LRSA departments. Such expert data are presented as speeches of the head of the LRSA, his deputies, heads of departments, offices, sectors, divisions, and services.

The analysis of the historiographical characteristics of the aggregated data published on the official Facebook pages.

1. The content of publications. To obtain generalized data, historians for their research can analyze the content of publications on the official FB page of the Lviv Regional State Administration. For example, if we study the process of politicization of the population of Lviv region, we can analyze the content of the head of the Lviv Regional State Administration to determine how much attention is paid to political issues in general and their democratic values, and then use the combined results of such an analysis as the only indicator of the democratic orientation of the region's population. The result of such a content analysis will be an indicator of certain community attributes.

2. Departmental statistics. The executive body of state power, the Lviv Regional State Administration, collects information related to its own activities. If these data meet the demands of a particular historical research project, they can be of great benefit to the research.

3. Information about the event that took place in the Lviv Regional State Administration. Historians are also interested in such information 
about individual events, which is not reflected in either census reports or departmental statistics, as these events are either too rare or even go beyond statistics. Examples of such events include the introduction of new projects / initiatives, the creation of new collegial bodies.

Information about such events can be useful in constructing indicators of any group properties. The process of collecting event information is very similar to content analysis. The relative reliability of event information can be ensured through careful training of the researcher and through control by those who regularly read the sources.

4. Expert data. If the data needed to construct the measurement of any particular aggregate properties does not exist, the historian may use the assessment of experts or persons familiar with the subject of the study. Expert data are presented in the speeches of the head of the executive body, his deputies, heads of departments, offices, sectors, divisions and services. However, they also have some drawbacks. First of all, the degree of accuracy of such data is limited by the personal experience of experts. To avoid the risk that the data is incorrect or incomplete, it is advisable to seek the help of several experts and verify their testimony.

The analysis of the historiographical characteristics of the aggregated data published on the official Facebook-pages of the LRSA is presented in Table 1.

\begin{tabular}{|l|l|l|}
\hline $\begin{array}{c}\text { The type of } \\
\text { aggregated data }\end{array}$ & \multicolumn{1}{|c|}{$\begin{array}{c}\text { Qualitative and } \\
\text { quantitative indicators }\end{array}$} & $\begin{array}{c}\text { Historiographical characteristics of } \\
\text { the aggregated data }\end{array}$ \\
\hline $\begin{array}{l}\text { contents of } \\
\text { publications }\end{array}$ & $\begin{array}{l}\text { contain some facts, } \\
\text { characterized by content } \\
\text { and timeliness }\end{array}$ & $\begin{array}{l}\text { - contain an expert assessment of } \\
\text { important and current events in the } \\
\text { region; } \\
\text { - are often indicators of the political } \\
\text { affiliation or preferences of civil servants }\end{array}$ \\
\hline $\begin{array}{l}\text { departmental } \\
\text { statistics }\end{array}$ & $\begin{array}{l}\text { contains numerical } \\
\text { characteristics of } \\
\text { objects and phenomena, } \\
\text { characterized by } \\
\text { objectivity and accuracy }\end{array}$ & $\begin{array}{l}\text { - reflect current statistics available to } \\
\text { the local executive body; } \\
\text { - is an important source base for } \\
\text { cliometric research }\end{array}$ \\
\hline $\begin{array}{l}\text { event } \\
\text { information }\end{array}$ & $\begin{array}{l}\text { contain a lot of factual } \\
\text { material, are complete } \\
\text { and reliable }\end{array}$ & $\begin{array}{l}\text { - provide brief information / overview } \\
\text { of major events; } \\
\text { - help researchers to clarify, refute } \\
\text { eyewitness testimony }\end{array}$ \\
\hline expert data & $\begin{array}{l}\text { contain an array of } \\
\text { consolidated data; } \\
\text { characterized by } \\
\text { relevance and importance }\end{array}$ & $\begin{array}{l}\text { - contain analytical reports, texts } \\
\text { of relevant structural subdivisions / } \\
\text { departments of the executive body; } \\
- \text { help researchers to make reasoned } \\
\text { historical conclusions }\end{array}$ \\
\hline
\end{tabular}


Conclusions. Thus, if in the process of research activities, historian, for some reason, can not use individual information or it is not available, it is rational to use aggregated data that contains the basic information he needs. Social networks are a unique platform where such aggregated data is published or generated and presented in free access. Based on the experience gained in the application of quantitative methods and information technology for the analysis of historical sources, we can conclude that new methods that provide additional opportunities in the study of study of important historical events, most effectively used in combination with traditional methods of source research.

In applied historical research, the situation or event itself is considered as certain integrity that has its own logic, sources of movement, growth limits, and other parameters. In this sense, the applied historical analysis should, if not explain, then at least rationalize and describe the factors of the historical process to predict further developments. In our opinion, applied historical analysis is fundamentally focused on the reflection of unique, individual events and situations. Its applied orientation involves the solution of certain universal problems in the study of the situation: the distribution of conditions, external context and localized events within their boundaries; identification of spatio-temporal parameters of the situation, showing the main limitations of the current actors of the historical period; separation of all entities operating in these circumstances; assessment of the balance of power of these entities; specific preconditions, reasons and factors influencing the behavior of subjects; consequences of emerging events. The main difficulties in applying applied historical analysis of aggregated data in identifying the factors of any socio-historical process are related to the ability to interconnect different approaches and techniques of research, combine conclusions and information obtained from qualitatively different methods.

Thus, an innovative and important element of the study of sociohistorical processes in Ukraine and in the world is the analysis of large arrays of statistical sources and aggregated data available through the official Facebook pages. On the basis of such analysis, the basic requirements of studying the particular problems, a search of the most acceptable their decisions, and definition of necessary for this purpose technological means and receptions of activity are formed. Studies of socio-historical processes by the method of quantitative analysis of aggregated data are designed to solve the problem of forecasting and modeling the further historical development of the city, region, country. 


\section{References}

Kovalchenko, I. D. (2003). Methods of historical research (second edition). [In Russian].

Owen, T. C. (1992). RUSCORP: A Database of Corporations in the Russian Empire, 1700-1914 [Computer file]. 3rd release. Inter-University Consortium for Political and Social Research. [In English].

Perelman, G. (2009). Comparative analysis of industrial stock prices on London and St. Petersburg exchanges in late XIX and early XX century. ECONOMIC HISTORY: YEAR BOOK (Vol. 19, pp. 53-105). Institute of Russian History RAS. [In Russian].

Perelman, G. (2005). Stock quotes on the St. Petersburg Stock Exchange in 18651914. Economic history: Review, Issue 11. [In Russian].

Borodkin, L. I. (2019). Historian and the world of (big) data: challenges of the digital turn. Historical informatics, 14-30. DOI: 10.7256/2585-7797.2019.3.31383 nbpublish.com. https://nbpublish.com/library_read_article.php?id=31383 [In Russian].

Borodkin, L. I. (2005). Historical information science at the bifurcation point: the movement to Historical Information Science. Circle of ideas: algorithms and technologies of historical Informatics. Proceedings of the IX conference of the Association "History and Computer". L. I. Borodkin, V. N. Vladimirov (Editors). pp. 7-21. [In Russian].

Borodkin, L. I. (2016). Modeling of historical processes: from the reconstruction of reality to the analysis of alternatives. [In Russian].

Borodkin, L. and Ertz, S. (2003). Coercion versus Motivation: Forced Labor in Norilsk. In The Economics of Forced Labor: the Soviet Gulag. Paul Gregory, Valery Lazarev (Editors). Hoover Institution Press/Stanford University. pp.127150. [In English].

Borodkin, L. and Leonard, C. S. (2000). The Rural Urban Wage Gap in the Industrialization of Russia, 1885-1913. Discussion Paper Series, 14. Department of Economics. University of Oxford. [In English].

Borodkin L., Granville B., Leonard C. S. (2007). The Rural Urban Wage Gap in the Industrialization of Russia, 1884-1910. CGR Working Paper 1 (September 2007). Qeen Mary, University of London. [In English].

Scharnhorst, A., Bosch, O., Doorn, P. (2012). Looking at digital research data archive. Visual Interfaces to EASY (April 2012). [In English].

Polyvovyi, N. (2014). Simulation Modeling of Political Instability and Maydan of 2013/2014 in Ukraine. European Journal of Transformation Studies, Vol. 2, suppl. 1. pp. 22-33. [In English].

Holub, S. \& Khymytsia, N. (2016, February). The use of multilevel modeling in the cliometric studies process. In 2016 13th International Conference on Modern Problems of Radio Engineering, Telecommunications and Computer Science (TCSET) (pp. 733-735). IEEE. https://doi.org/10.1109/ TCSET.2016.7452166. [In English]. 
Holub, S. \& Khymytsia, N. (2018, August). The Method of Cliodinamik Monitoring. In 2018 IEEE Second International Conference on Data Stream Mining \& Processing (DSMP) (pp. 223-226). https://doi.org/10.1109/ DSMP.2018.8478459 [In English].

Khymytsia, N., Lisina, S., Morushko, O., Zhezhnych, P. (2017). Analysis of Computerbased Methods for Processing Historical Information, Advances in Intelligent Systems and Computing. Selected Papers from the International Conference on Computer Science and Information Technologies, CSIT 2017, September 5-9 Lviv, Ukraine, Shakhovska N. (Ed.). (Vol. 1, pp. 365367). Springer International Publishing. [In English].

Khymytsia, N., Ustyianovych, T., \& Dronyuk, I. (2019). Identification and modeling of historiographic data in the content of web forums. In CEUR 1st International Workshop on Control, Optimisation and Analytical Processing of Social Networks, COAPSN 2019 Proceedings. (Vol. 2392, pp. 297-308). [In English].

Mannheim, J. B., Rich, R. K. (1997). Political Science: Research Methods. [In Russian].

Надійшла до редколегії 9.09.2021 